УДК [352/354:321.02](6-15)

DOI 10.30970/vir.2019.47.0.10454

\title{
TRADITIONAL CHIEFTAINCY AS POLITICAL INSTITUTIONS IN WEST AFRICA
}

\author{
Harouna Zongo \\ Ivan Franko National University of Lviv, \\ 1, Universytetska Str., Lviv, Ukraine, 79000, tel. (032) 239-41-32, \\ e-mail:zongoharoun@gmail.com
}

The African continent has undergone a long process of social reorganization and today, in its socio-political structure, it differs little from other continents. West Africa is an excellent example of these changes. It is therefore important to underline the enormous role that traditional leaders have played and continue to play in Burkina Faso, Mali, Côte d'Ivoire, Niger, Guinea, Nigeria and Ghana. Before the colonial period, the West African states were powerful empires whose social and political systems played an important role until today. Among them are the empire of Ghana, Mali, Sonrhai, Wassoulou, the kingdom of Liptako and Kénédougou. Despite their decline, African societies have been able to retain some forms of pre-colonial organizations. Thus, at the end of the colonization and emergence of modern states in Africa, we find structures rooted in popular cultures and traditional diplomacy greatly contributes to conflict resolution and social cohesion. In most West African countries, there is a wide variety of chieftaincies. For example, in Burkina Faso, there are the Mossi kingdoms, the Soninke principality of Ouahabou, the principality of Barani, the kingdom of Liptako. In Ghana there are the kingdoms Akan, Eve, Gan, Gurma, Adangbe. The main objective of this study is to highlight the existence of these kingdoms in West Africa, in order to determine the influence of the traditional chiefdoms of the pre-colonial period on the modern economic, social, political and cultural life of these countries.

Key words: Chiefdom; traditional; Kingdom; Africa; West Africa.

The countries of West Africa, like other countries of the continent, were organized and run by local authorities who had imagined a multitude of types of societies and various forms of organization to make social cohesion possible. There are hierarchical societies and egalitarian societies. Hierarchical societies operated under the direction of power whose name differed from one locality to another.

The term chief is only a creation of the colonists to designate the native powers of their colonies. In some French documents, one encounters the use of the expression «commandement indigène». In the English documents, the term used is 'chief' instead

(C) Zongo Harouna, 2019 
Harouna Zongo

ISSN 2078-4333. Вісник Львівського університету. Серія міжнародні відносини. 2019. Випуск 47

of 'king' to mark the difference from the rulers. It is these powers that the European colonizer will overcome before settling and administering African lands.

The African authorities are going to oppose to the invaders a fierce resistance to their will to keep inviolate the lands of their ancestors. Unfortunately, all resistance has almost been defeated. Some traditional leaders will be captured, deported, forced into exile or killed. This is the case of King Gbehanzin of Dahomey, Almamy Samory Touré deported to Gabon where he died in 1900; of Mogho Naaba Wobgo who fled to Ghana until his death.

Samory Touré was born in 1830 in Miniambaladougou (now Guinea Conakry). He began his career as a trader who took advantage of the trans-ocean trade around activities such as gold trading, the slave trade and the arms trade. This trade allowed him to get rich, to build up a stock of weapons for the war, the financial power allowing him to gather around him dedicated and very ambitious people.

In 1850, the mother of Samory Touré Masorona Kamara is captured. Samory is forced to engage in military service to secure his mother's release. According to the legend, he performed «7 years, 7 months and 7 days» before taking his mother and running away with her. This military service allowed him to learn the handling of weapons, to show himself a good soldier and warrior, and therefore to discover that his vocation is war more than trade. it was the beginning of Samory Touré's ascent. [5, p. 375-376].

He joins the Bérété army. He is named Keletigui (warlord) during a ceremony where he takes an oath and promises to protect his people against the Cisse kingdoms. He creates a professional army led by men in whom he has extreme confidence (his brothers, his childhood friends, and his sons later) and begins the conquest that will lead to the future formation of his empire the Wassoulou whose capital will be Bissandougou. Its empire extends (from west to east) at its peak from Upper Guinea to Upper Volta (now called Burkina Faso), through northern Côte d'Ivoire. The tropical forest in the south and the Sahara in the north formed the other limits of his empire.

The traditional societies of the conquered peoples are preserved, but also, they are capped by a military administration that takes a heavy toll and keeps the men for their incorporation into the army of Samory Toure. Also, the animist populations are Islamized by the way, and Samory Toure also takes the title of Almany (commander of the believers).

From 1880, Samory Toure will collide with the English and especially French colonists who wanted to penetrate the interior of the African continent. Indeed, the French wanted to make the junction between their colonies of Senegal and Ivory Coast. The prestige of Samory Toure becomes immense when he repeatedly defeated the French troops, especially during the Battle of Woyowayanko April 2, 1882 despite the superiority of the French who had heavy artillery.

He later played the diplomat trying unsuccessfully to oppose the French and English. He also signed several treaties with the French, and even sent one of his sons to France. Samory also tried to limit its technological backwardness by asking artisans to copy the weapons bought or confiscated from Europeans. However, it will popularize the concept of «scorched earth strategy», which consisted of shaving 
everything in its path in order to curb the progress of the enemy. It was obviously guerrilla warfare rather than war, but given the technological inferiority it was difficult for him to always counter the French forces. Nevertheless, Samory was able to defeat the French colonists for several years thanks to this strategy and its military foresight.

Unfortunately, cohesion in his constituted (and especially Islamized) empire of strength was lacking. A «war of refusal» will even agitate the kingdom in 1889, led by animist subordinates, who were against forced Islamization. His family will tear up on the question of negotiating or not with France, and Samory will even execute the son he had sent to France in the past.

His strategy of the «scorched earth» showed limits to the French generals who will learn to limit the effects, and Samory made the mistake of wanting to extend his empire by the North of Ivory Coast. this desire for extension was beyond the forces of his Empire, devoid of arms and allies. Samory was betrayed by his family as he negotiated his surrender. he was arrested on 29 September 1898 by Commander Gouraud, and was exiled to Gabon where he died of pneumonia on 2 June 1900. On September 28, 1968, his ashes are brought back to Guinea led by Sékou Touré.

After these victories over African commanders, the Europeans will impose their control system for the enrichment of European capitals. The political systems (traditional management) in place in Africa have been replaced by voting systems. A new model of governance, such as a European model, has been introduced. African leaders then abandoned traditional state management.

Nowadays, some West African countries that have been able to keep the traditional chiefdoms are able to use these chieftaincies, which play a very important role in times of crisis. By adopting a neutral position, they act as mediators in situations of conflict between ethnic groups, between political parties or between states. For example, Mogho Naaba's mission of promoting peace is a sacred duty. Indeed, one of the duties of the sovereign is to ensure the tranquility of his people. This is why we see that calls for peace by Mogho Naaba are recurrent. Here we will take some examples to support our statement.

First of all, let us note that at the time of the Ivorian crisis, dismayed by the mass arrivals of Burkinabe fleeing the war, Mogho Naaba Baoogo asked for prayers for the return to peace and cohesion between Burkinabe and Ivorians. On January 24, 2008, when he received in his palace the visit of President Laurent Gbagbo, the Mogho Naaba surrounded by two other (Dima) kings, Naaba Saaga of Tenkodogo, Naaba Son of Boussouma and of course his ministers (Ouidi-Naaba Karfo, Larle-Naaba Tigray, Baloum Naaba expressed his gratitude to the Ivorian head of state and sent a message of peace, indeed, he prayed for the final return of peace in the sister Republic of Côte d'Ivoire.

This call was reiterated by the current Ivorian President Alassane Dramane Ouattara [4, p. 2-3].

West Africa has long been undermined by conflicts of all kinds since independence. These conflicts constitute enormous obstacles to the socio-economic development of the countries. It will be for us in this study to highlight the specificity of traditional chiefdoms in some West African countries [6, p. 212]. 
Harouna Zongo

West Africa is made up of fifteen states. This zone includes eight (8) Frenchspeaking countries (Benin, Burkina Faso, Ivory Coast, Guinea, Mali, Niger, Senegal and Togo), five (5) English-speaking countries (Gambia, Ghana, Liberia, Nigeria and Sierra Leone). and two (2) Lusophone countries (Cape Verde and Guinea Bissau). This African region is characterized by the existence of traditional chiefdoms alongside modern administrations. These two institutions maintain sometimes conflictual relations, sometimes peaceful. Understanding these customary powers requires an analysis of societies. At first glance, it can be seen that each West African state has had the historical experience of experiencing traditional chiefdoms before colonization. Independence will enable Africans to self-administer and choose their leaders. This Western system of choice will allow the emergence of new powers. In their style of administration, the new states will be forced to solve the chieftaincy equation. So, each State will reserve a particular treatment to the chieftaincy according to the philosophy of the leaders. The treatment of chieftaincy will vary from state to state.

Africa, like the other continents of the world, has known in its history the phenomenon of war as «unavoidable social pathology» and «it is precisely because violence (open or latent) was omnipresent that African societies have implemented mechanisms and procedures to manage conflict» [7, p. 212].

The historical existence of traditional chiefs in almost all West African states is well established. Indeed, all these states know or have known the chieftaincy institution. The study of chieftaincy in some states shows that chieftaincy is a shared legacy in some states.

The law on the status of kings and traditional chiefs of 11 July 2014 on the chiefdom in Côte d'Ivoire distinguishes five (5) categories of kings and traditional chiefs. There are kings, provincial chiefs, canton chiefs, tribal chiefs and village chiefs divided among the different ethnic groups of the country. The Ivorian population is divided according to BLEKANH K. FAUSTIN into four major ethno-linguistic groups namely Krou, Alan, Gur and Mande. Each group is typically organized in chieftaincy.

The traditional chiefdom among the Krou is a political power generally circumscribed at the village level. In the need to defend broader interests, an alliance system has been put in place. Since the 19th century, this power has undergone a mutation to expand in the economic, military, and social fields. The designation of the chief is made according to values in particular: «the old age is a sign of a capital of wisdom, the personality which forces the respect, the wealth and the generosity (...), the physical force because the war is a means conflict resolution» [1, p. 23].

Traditional Gur or Voltaic chieftaincies are organized in a much larger sphere than the Krou. Placed under the control of a chieftaincy, the organization of power is done according to two plans, namely the social plan and the political plan. Power is then organized on a generational basis (in age classes) and on a political basis. A Gur village is composed of four age classes: «that of children ( 0 to 15 years), that of adolescents (from 15 to 30 years), that of adults (30 to 45 years) and that of old (45 years and older)». 
As for the political organization, it is set up a sort of government that imposes itself on everyone. It is created a system of land chief. The first person to occupy an uninhabited land is the land chief. This person plays a role of chief of the village and the succession is done on a hereditary basis. He is the intercessor with the ancestors, the first landowners. Those who are under his control «are bound to give him days of labor on his land».

The traditional chiefdom of Mandé is divided into Mandé South and Mandé Nord. The organization of power is not the same. Mande South is organized in village chieftaincy, while Mande North is organized into kingship. South Mande is part of «anarchic societies or stateless society or village democracy». Political activity is exercised around the social structures constituting the institutional frameworks. «This is the lineage district, the village and the tribe» (...) «the authority is of a senior nature and is transmitted in order of male primogeniture between brothers». Elders are responsible for resolving land and inheritance issues. Then there are the masks that maintain the order and are the spokespersons of the ancestors. Masks then constitute an undisputed authority.

The North Mandé is a monarchy where there is a «faama» or «mansa». The mansa or faama is a very powerful monarch. It has a power at the same time political, military and judicial. A sacred authority, no one has the right to speak directly to him. $\mathrm{He}$ is assisted by councils, governors and an army. The councils are composed of three groups that are: «that composed by the representatives of the districts of the city and opened to the men of more than 50 years, that of the old ones which is placed under the effective authority of the king and which gathers all the military governors, the princes of blood and the delegates of all socio-professional layers, finally the council of the king who gathers the brothers and the girls of the mansa». The kingdom is built around a language and is divided into provinces that are entrusted to the king's sons.

The Akan traditional chiefdom is very centralized. The king is sacred. «The Akan monarchy, without divine right, is based on the acceptance by all of the superiority of a royal clan that holds a hereditary and almost absolute power». Kingdoms contain provinces subdivided into villages. The symbol of power is the «bia» or throne. There are several categories of bia but the most prestigious is the authentic bia. This throne is awarded with inheritance in matrilineal succession. Women are the repositories of the power exercised by men. They are therefore owners and responsible for the bia. There is a queen-mother who intervenes in case of incompetence of the king. It ensures the interim in case of vacancy of power. His voice is preponderant in the choice of heirs.

In Niger, according to Mahaman Tidjani Alou, the chieftaincy has an existence rooted in the history of the country in the sense that it «has always been a strategic player on the nigerien political scene». As a result, «researchers often question the reasons for this positioning. Chief has been found among sedentary peoples and nomadic pastoralists in the Sahel».

In this country too, the chieftaincy has had difficult times with the colonizer. Indeed, the French have instrumentalized the traditional powers by making subordinates, commanders of circles. The chieftaincy in this country has been influenced by the settler because, according to Mahaman Tidjani Alou, «the 
Harouna Zongo

ISSN 2078-4333. Вісник Львівського університету. Серія міжнародні відносини. 2019. Випуск 47

chieftaincy institution in its present configuration owes much to the colonial administration which gave it its semantic and institutional outlines» and the word «chieftaincy» is an invention of the colonizer to designate the forms of organization he encounters among Africans. Another possible name for African power is given by William Ponty who considers «commandement indigène» in 1909. Later, one will meet the name «customary chief» then of «traditional African chieftaincy». The chieftaincy as it still exists in Niger is the result of a colonial reform that has not always taken into account the realities of the country.

The traditional chiefdoms in Ghana, as everywhere else in West Africa find their sources in precolonial Africa and were depositories of a concentrate of powers namely: executive, legislative, and judicial. We can mention: Akan, Ewe, Gan, Gurma, Adangbe etc. The British colonist did not deny the «Native Authorities» who were also incorporated under the English indirect rule. However, this consideration of the chieftaincy aimed to guarantee the interests of the settler and to pervert the traditional authorities who had become taxable persons of the British colonial administration. Better still, the colonizer will tarnish the image of the chieftaincy by rendering obsolete the democratic principle of the popular control of the chiefs. This principle would require that the legitimacy of the leader always be based on popular support. Indeed, this support was no longer important when the customary authority enjoyed the confidence of the colonizer. She no longer needs this support.

In Ghana, the traditional chiefdoms that occupy most of Ghana's territory have their origins in the pre-colonial organization. They were central to the exercise of executive, legislative and judicial powers. They were not formally abolished during the British presence in the Gold Coast. During the British occupation, the prerogatives of the chiefdoms, the Native Authorities, were guaranteed by the Indirect Rule, set up from 1878, extended to the whole country in 1904. The texts in practice gave a statutory basis to the chiefs traditional. But behind this recognition, it was a way of guardianship. chieftaincies had become «effective but alienated relays of the administration» $[12$, c. 55].

To use the expression of N. Chazan, An Anatomy of .... At the same time, the mode of control of traditional power reversed itself: «The democratic principles which were at the base of the organization of the chiefdoms in Ghana and which made that the chiefs were indebted towards their subjects cracked. the recognition of traditional leaders by the colonial authority had become more important than the support of the people» [ 8, c. 403].

S. A. Nkrumah, «Decentralization for Good Governance and .... Downward accountability» was replaced by «upward accountability» (the duty to report to the colonial authority). After 1920, conflicts calmed down, especially in the Ashanti country, the most rebellious clan. The Watson Commission, which was established by the British Crown after the 1948 Accra People's Riot, noted the danger of this situation and made it the cause of growing unrest in the colony. The resentment born of this exclusion was the breeding ground of Ghanaian nationalism. One of the highlights of the claim of the nationalist and liberal intelligentsia reunited around Joseph Danquah, Edward Akufo Addo and William Ofori Atta. In 1957, on the eve of 
Independence, draft Constitution circulated; they proposed the establishment of a bicameral system in which the Council of Chiefs would become the Senate next to an elected People's Assembly. The Senate was never established, but the first Constitution of Independence adopted an intermediate formula by creating the Regional Houses of Chiefs to replace the three Provincial Councils of the Gold Coast which had been created in 1925 by the colonial governor Guggisberg. A dual system was put in place. After various vicissitudes, it still remains in force today.

After Independence, relations between chieftaincy and political power were just as chaotic. Like many socialists of his time, Kwame Nkrumah felt that chieftaincies had compromised with colonial rule and were an obstacle to the modernization of the country. His goal was to liberate the people from the slavery in which foreign colonialism maintained it and from the tyranny of local feudal despotism [7, c. 403].

Kwame Nkrumah «Movement for Colonial Freedom», Phylon .... The penalty was pronounced: «The Chiefs would run away and leave their sandals behind». The Native Authorities courts were dissolved. Whenever a leader showed his independence, the party organized a smear campaign to remove him.

In 1966, after the overthrow of Nkrumah, the ruling army realized that traditional chiefs could play the role of arbiter in Ghanaian society. A useful function to calm the political game inside Ghana. This vision of traditional chieftaincy had been lacking in Nkrumah. Traditional leaders thus regained the autonomy of their political space. consequently, they unabashedly accepted the nepotism of the rulers in uniform. In 1969, the Constitution of the Second Republic established the National House of Chiefs, composed of five Paramount Chiefs from the various Regional Houses. The attributions of these institutions remained purely customary. The traditional leaders taking care not to get too involved in the political life particularly agitated at the time.

With the adoption of the constitution, the Senate was abandoned but it creates a National House and Regional Houses of the chiefs. In 1971, through the adoption of the Chieftaincy act, the decentralization policy took into account the chieftaincy. The Local Government Law of 1988 and the Constitution of 1992 will legally establish the chieftaincy. These acts underwent many modifications and transformations certainly, but remain essentially in force.

In Nigeria, the chieftaincy is an institution to which many communities continue to identify. Terms used to refer to traditional leaders differ from one society to another. In the north of the country of Muslim obedience, the qualifier Emir is the most common. There are also appellations in local languages such as Sarki, Shelu, Mai, Lamido etc. In the Southwest, Oba is the noblest qualifier for a traditional high chief in the Edo and Yoruba communities. Titles like Alake, Alaafin or Olun'wo are also commonly used. In the South and Southeast, Obi, Igwe and Eze are titles of nobility designating Ibo leaders. Other minority communities use the terms Amanyanabo, Father, Orodje, Obong etc. The English had established a classification according to their degree of influence. So, we have paramount rulers and second leaders. Among the most prestigious chefs, we first mention the Ooni of Ife and Alaafin Oyo. The Emir of the North of the country, such as the Emir of Kano and the Sultan of Sokoto. 
In villages, village chiefs exercise power, apply custom and conciliation among citizens [3, c. 3-4].

In Burkina Faso, the situation in Burkina is similar to that of neighboring countries. The birth of the states began very long under the leadership of the chiefdoms, continued until the arrival of Europeans in Burkina Faso. This is well summed up by an author for whom «the process of constitution of the Voltaic States continued in the $16^{\text {th }}-17^{\text {th }}$ century the Dagomba swarming the kingdoms of Bouna and Wa, the Mossi states being multiplied by fission and by territorial conquest. So, there is not one «Empire Mossi», but twenty different kingdoms of mossi. The most important is the kingdom of Ouagadougou. Here the royal power is exercised by the relay of provincial chiefs, whose political influence covers several peripheral kingdoms» [13, c. 219].

In north Burkina Faso, there is the other major entity, the Yatenga. In the East, the kingdom of Boussouma. Many other political entities outside the Mossi kingdoms are listed as the Liptako, the Gan of Obire kingdom, the Poula principalities, and so on [5, c. 421].

\section{BIBLIOGRAPHY}

1. BLEKANH Kouadio Faustin, Une démocratie à l'africaine pour un développement durable : cas de la Cote d'Ivoire, Paris, L'Harmattan, 2009. - P. 23.

2. C. Abotchie, A. Awedoba, I. K. Odotei et al., «Perceptions on Chieftancy», in Irène K. Odetei et Albert K. Awedoba, Chieftancy in Ghana, Culture, Governance and Development, Accra, Sub-Saharan Publishers, 2006. - P. 109.

3. Chefferie traditionnelle au Nigeria : Etude OFPRA, 6 Février 2015.

4. Confer l'observateur Paalga 7057 du vendredi 25 au dimanche 27 janvier 2008.

5. Histoire de l'Afrique Noire Joseph Ki-Zerbo. - P. 375-376.

6. Joseph R. A. Ayee, Decentralization and Good Governance in Ghana, unpublished paper, May 2000, Accra (Canadian High Commission). - P. 12.

7. Kandé Mamadou Alioune (citant Doulaye Konate) dans sa thèse de doctorat sur le thème : le conflit Casamançais, Origines historiques et prolongements actuels, Université de Toulouse, 2016. P. 212.

8. Kwame Nkrumah, «Movement for Colonial Freedom», Phylon (Atlanta), 1955. - P. 403.

9. Pour reprendre l'expression de N. Chazan, An Anatomy of Ghanaian Politics: Managing Political Recession, 1962-1982, Boulder, Westview, 1993.

10. Mariano Pavanello consacre son article à un commentaire de la Constitution sur ce point : «Le paradoxe de la chefferie constitutionnelle au Ghana», dans Claude-Hélène Perrot et François-Xavier Fauvelle-Aylar, Le retour des chefs, Paris, Karthala, 2003.

11. Ouedraogo Albert, Démocratie et cheffocratie ou la quête d'une gouvernance apaisée au Faso, oralité et traditions, Ouagadougou, PUO, 2014. -268 p.

12. S. A. Nkrumah, «Decentralisation for Good Governance and Development: the Ghanaian Experience», Regional Development Dialogue, vol. 21, $\mathrm{n}^{\circ}$ 1, 2000. - P. 55.

13. Tiendreobeogo Yamba, Histoire et coutumes royales des Mossi de Ouagadougou, Ouagadougou découvertes du Burkina, 2010. -219 p. 
Harouna Zongo

ТРАДИЦІЙНІ ВОСВОДСТВА ЯК ПОЛІТИЧНІ ІНСТИТУТИ У КРАЇНАХ ЗАХІДНОЇ АФРИКИ

\author{
Хароуна Зонго \\ Львівський національний університет імені Івана Франка, \\ вул. Університетська, 1, м. Львів, Украӥна, 79000, тел. (032) 239-41-32, \\ e-mail: zongoharoun@yahoo.fr
}

Африканський континент пережив довготривалий процес соціальної реорганізації і сьогодні за своїм соціально-політичним устроєм мало чим відрізняється від країн інших континентів. Західна Африка є яскравим прикладом цих змін. Тому важливо виділити величезну роль, яку традиційні лідери відігравали та продовжують грати у Буркіна-Фасо, Малі, Кот-д’Івуарі, Нігері, Гвінеї, Нігерії, Гані. До колоніального періоду західноафриканські держави були могутніми імперіями, соціальний та політичний лад яких відіграє чималу роль і сьогодні. Серед них виділяємо імперію Гани, Малі, Сонхай, Вассулу, королівство Ліптако та Кенедугу. Незважаючи на їхній занепад, африканські товариства змогли зберегти навіть доколоніальні форми організації. Таким чином, наприкінці колонізації та виникнення сучасних держав в Африці ми знаходимо структури, закріплені в популярних культурах, а традиційні воєводства у великій мірі сприяють вирішенню конфліктів та соціальній згуртованості. У більшості країн Західної Африки існує велика різноманітність вождів. Наприклад, у Буркіна-Фасо зустрічаються королівства Моссі, князівство Сонінке Уахабу, князівство Барані, Королівство Ліптако. У Кот-д’Івуар це королівство Кру, царство Гур, королівство Акань, у Нігері - царство кочового народу і царство осілого народу. У Гані - аканські царства, Еве, Ган, Гурма, Адангбе. Основною метою дослідження є вивчення історії королівств держав Західної Африки для визначення вливу традиційних воєводств доколоніального періоду на сучасне економічне, соціальне, політичне та культурне життя країн.

Ключові слова: вождь; традиція; Королівство; Африка; Західна Африка. 